\title{
Limited Liability Partnership
}

National Cancer Institute

\section{Source}

National Cancer Institute. Limited Liability Partnership. NCI Thesaurus. Code C54136.

A type of company, authorized only in certain states, whose owners and managers

receive the limited liability and (usually) tax benefits of an S Corporation without having to conform to the $\mathrm{S}$ corporation restrictions. 